UDC 54.138:54.05:623.454

\author{
Z.O. Znak, Yu.V. Sukhatskiy, A.B. Helesh, R.V. Mnykh
}

\title{
ENERGY-CONDENSED COMPOSITIONS FOR GENERATION OF BLACK AEROSOL CLOUDS
}

\author{
Lviv Polytechnic National University, Lviv, Ukraine
}

\begin{abstract}
The paper reports the influence of additives with different chemical nature and functional purpose (magnesium carbonate and thiourea) on the processes of generating black aerosols, in particular, the uniformity of the combustion of compositions, the duration of intense smoke and the density of the aerosol cloud. It is established that the addition of magnesium carbonate (flame extinguisher) to the anthracene composition in the amount exceeding 0.2 wt.\% increases the duration of combustion initiation (by 2-2.4 times) and decreases the flame height and flash frequency. In this case, the duration of intense smoke decreases by $6.7-11.1 \%$, and the total average duration of the aerosolization process (i.e. the duration of combustion initiation together with the duration of intense smoke) remains unchanged and is about $50 \mathrm{~s}$. It is found that an increase in magnesium carbonate content in the composition of more than $0.5 \mathrm{wt} \%$ significantly complicates ignition. Therefore, it is necessary to increase the content of oxidant (potassium chlorate) in the composition to achieve the required combustion temperature. An increase in magnesium carbonate content in anthracene compositions from 0.8 to $1.5 \mathrm{wt} . \%$ (while reducing anthracene content) causes an increase in the total duration of aerosol formation by 1.7 times (from 39 to $65 \mathrm{~s}$ ) and ensures compliance with its basic characteristics (the uniformity of combustion of compositions, the duration of intense smoke and the density of the aerosol cloud). The reduction of the duration of combustion initiation of the anthracene composition (by 1.7 times) and the duration of intense smoke emission (by 25\%) was observed when increasing the thiourea content in the composition from 0.2 to $1.0 \mathrm{wt} . \%$. The possible areas of the use of anthracene compositions with the additives of magnesium carbonate and thiourea are military sphere (to generate aerosol clouds of black color with masking properties for the protection of personnel and equipment) and filming (to imitate the battle scenes), respectively.
\end{abstract}

Keywords: energy-condensed composition, anthracene, aerosol, black smoke, camouflage ability, magnesium carbonate, thiourea.

DOI: $10.32434 / 0321-4095-2020-129-2-60-66$

\section{Introduction}

Nowadays, increasing the technical capabilities of the armed forces is a top priority of any independent state. Therefore, developed countries pay a lot of attention to provide their own armies with modern weapons, ground, air, space exploration and weapons control.

The most effective means of defeat are highly accurate means that allow selectively destroying ground targets. The analysis of the recent hostilities clearly shows a rapid increase in the number of highprecision aircraft and clearly underscores the urgency of reducing the visibility of troops and facilities.
The most common means of masking objects of various scales from the reconnaissance and targeting weapons of the enemy are masking aerosols and other airborne dispersion systems that provide appropriate action in a wide variety of ranges: visible, infrared, radar, etc.

In addition to military applications, aerosol generation is also carried out in agriculture (for the cultivation of agricultural land, for pest control and for the protection of frost gardens during the flowering period) and in fire protection technology (the ignition and propagation of the aerosol cloud flame from components that have a high flame retardant 
capacity).

Therefore, the development of cheap energycondensed compositions for the production of aerosol generators of various purposes is a very important and relevant task.

The masking properties of aerosols are based on two physical phenomena: the scattering of light and its absorption [1]. It should be noted that a part of the space of the cloud of aerosol particles, which reduces the optical visibility of personnel and objects to the required level and creates obstacles to the optical and radar means of reconnaissance and targeting enemy weapons, is referred to as the aerosol cloud.

Light scattering is the deflection of particles of rays that pass through the aerosol cloud. The scattering by a single particle is determined by the set of refraction, reflection and diffraction processes of radiation [2]. The contribution of scattering processes depends on the radiation wavelength, the size and the properties of the particle. The absorption of light is accompanied by the transformation of the energy of light quanta into its other types: thermal, electrical and chemical.

Aerosols are dispersion systems consisting of small solid or liquid particles (dispersed phase) distributed in gas (dispersion medium). Depending on the particle size and the aggregate state of the dispersed phase, the aerosols are divided into dust, smoke and fog [3].

In military camouflage smoke (dispersed systems consisting of solid particles with the size of 0.001 to 0.1 microns) are used to conceal the movement of troops, blinding the enemy with the purpose of neutralization of its actions, imitation fire military equipment, alarms and so on.

The main masking fumes are the so-called «white» and «black» fumes. The difference in color is explained by the different scattering and absorption of light in these fumes. Thus, in white smoke, the proportion of absorbed light is only $10-30 \%$ of the total amount of the scattered and absorbed light. Therefore, light scattering plays a major role in attenuating light rays in white smoke. In black smoke, the proportion of absorbed light is much greater than in white, and is about $80 \%$ of the total amount of the scattered and absorbed light. Therefore, in black smoke, the main role in the attenuation of light rays is its absorption.

Different wavelengths are scattered by the same kind of smoke differently: the closer the average particle size is to the wavelength of light, the more efficient the scattering occurs. Infrared radiation has wavelengths much larger than the particle sizes in white smoke aerosol clouds, so white smoke is less masked in the infrared region than in the visible range of the optical spectrum. For masking in the infrared spectrum, phosphorus fumes are more effective [1] since they form sufficiently large particles of fog or mixtures of black smoke.

Pyrotechnic mixtures (energy-condensed systems) for generation of aerosol clouds contain three main components: oxidizer, fuel and smoke generator [4]. The compositions of black aerosol clouds typically include potassium chlorate $\left(\mathrm{KClO}_{3}\right)$ as an oxidant [5] and fatty or aromatic hydrocarbons (commonly, naphthalene and/or anthracene) [6,7]. Hydrocarbons perform not only smoke-forming role but also serve as a fuel that can be partially sublimated and partly combusted [4].

Thus, a mixture of the following composition was used to generate aerosol black clouds during cinema scenes [8] (wt.\%): potassium chlorate 55 and anthracene 45 . The moisture content in potassium chlorate did not exceed $2 \mathrm{wt} . \%$. The duration of the intense smoke formation was 2 minutes (the weight of the mixture was $1.4 \mathrm{~kg}$ ).

In order to simulate a fire source during filming, the following composition was used to generate black smoke [4] (wt.\%): potassium chlorate 53-58, anthracene $40-43$ and thiourea $2-4$. The content of anthracene oil in anthracene coal crude was 25 wt.\%. The combustion rate of this mixture was $1.0-1.5 \mathrm{~mm} / \mathrm{s}$. This formed a stable dense cloud of saturated black.

A pyrotechnic mixture of black smoke composition contained [9] (wt.\%): potassium chlorate 52-55, anthracene 33-37, thiourea $6-10$ and phenol-formaldehyde resin $3-5$. The maximum smoke-forming capacity of $90 \%$ was achieved by the total content of combustion activators (thiourea and phenol-formaldehyde resin) in the mixture in the range of 10 to $15 \mathrm{wt} . \%$. The burning rate of the mixture was $1.6-2.0 \mathrm{~mm} / \mathrm{s}$ and the slag content was reduced to $10-15 \%$.

The use of pyrotechnic compositions to simulate the undermining of artillery ammunition (mines, grenades, etc.) is accompanied by a characteristic sound effect [10]. The combustion of the composition (potassium chlorate of 50-54 wt.\%, powder of aluminum-magnesium alloy of $35-37$ wt. $\%$ and anthracene coal crude of 11-13 wt.\%) occurs with a high rate and a high temperature of the products of combustion. A «jump» of density is observed for these mixtures, which is caused by a sharp whistle in the course of the formation of a cloud of black smoke.

It should also be noted that the effectiveness of the masking action depends on the spatial, 
temporal and optical characteristics of the aerosol cloud $[7,11,12]$.

The purpose of this study was to investigate the effect of different chemical additives on the processes of aerosol generation, including the uniformity of combustion of compositions, the duration of intense smoke and the density of the aerosol cloud.

\section{Experimental, results and discussion}

The efficiency of aerosol cloud generation depends on the procedure of raw materials preparation, the uniformity of mixing of their components, the mass ratio between the components (i.e. chemical composition) and the method of the compaction and formation of compositions for smoke generation.

Preparation of raw materials (potassium chlorate, technical anthracene, magnesium carbonate, etc.) to obtain compositions for the generation of black smoke cloud involved the grinding and homogenization of the components in a ball mill to obtain a pyrotechnic composition with homogeneous color and dispersity. The components were treated in the mill for $900 \mathrm{~s}$.

Compaction and formation of mixtures for the generation of the smoke cloud was carried out by pressing. The pressing of the mixtures was performed at a total pressure of 1.0-1.4 $\mathrm{MPa}$. At these pressures, dense tablet-shaped elements were formed, which retained their shape and did not collapse under the influence of moderate mechanical loads.

The means for generating a smoke cloud consisted of two elements of the compressed mixture weighing $97 \mathrm{~g}$ each. The pressed elements were placed in a mold (housing) with all the necessary structural details (element of initiation, grilles, covers, fuses, etc.).

Timers and video were used to record two indicators of the process: the duration of initiation of intensive combustion process and the duration of intense smoke.

The aerosol generation efficiency was evaluated by the uniformity of combustion of the compositions, the duration of intense smoke and the density of the aerosol cloud.

Energy-condensed compositions (pyrotechnic mixtures) for the generation of masking fumes usually contain three main components: fuel, oxidant and smoke. To produce aerosol clouds of black color, anthracene compositions are mainly used. In these compositions, anthracene acts not only as a smoke generator but also as a fuel, partially sublimated and partly combusted. Potassium chlorate is used as the oxidizing agent.
Various additives to the composition of energycondensed compositions can be used to eliminate flares, ripples during combustion of compositions and to provide the required duration of initiation of their combustion process and uniform formation of the aerosol curtain over time.

Often, uncontrolled flashes and ripples (Figure) are observed during the combustion of compositions, i.e. the burning uniformity is disturbed. Hence, flame arresters are added to the compositions to eliminate compositions [5]. Typically, these are endothermic compounds (sodium, calcium or magnesium carbonates), which during thermal decomposition produce carbon dioxide that dilutes the gaseous reaction products with air.

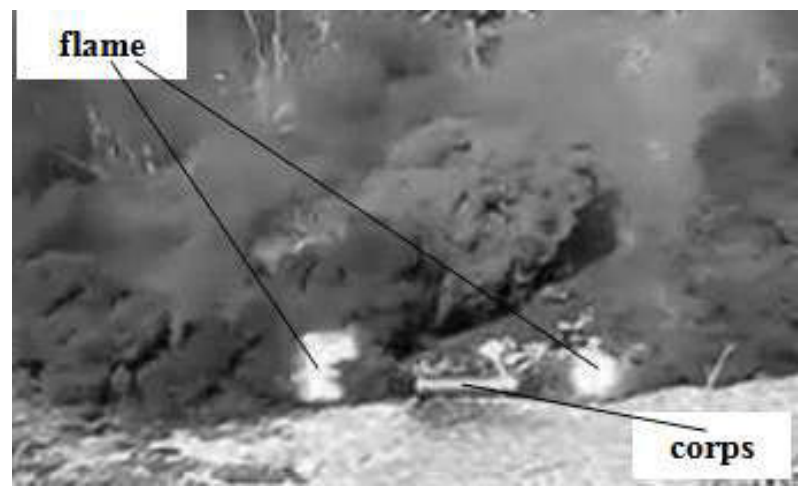

Flashes observed during the combustion of anthracene compositions

Magnesium carbonate was used in this study as a flame extinguisher during the combustion of anthracene compositions. The effect of magnesium carbonate on the characteristics of the aerosol formation process is shown in Table 1.

It was established that the addition of magnesium carbonate to the composition (Table 1) for the generation of black smoke cloud in the amount that exceeds $0.2 \mathrm{wt} . \%$ reduced the height of flames and the frequency of flares. At the same time, the duration of intense smoke was decreased by $6.7-$ $11.1 \%$. However, it should be noted that the total average duration of aerosol formation (the duration of initiation of combustion and the duration of intense smoke) was almost unchanged and was about $50 \mathrm{~s}$.

An increase in the content of magnesium carbonate in the composition of more than $0.5 \mathrm{wt} . \%$ prevented its ignition. A further increase in the content of magnesium carbonate in the compositions from 0.8 to $1.5 \mathrm{wt} . \%$ caused an increase in the total aerosol formation duration by 1.7 times (from 39 to $65 \mathrm{~s}$ ). Therefore, the content of magnesium carbonate in the composition of $1.5 \mathrm{wt} . \%$ (composition no. 11 
Table 1

Effect of magnesium carbonate on the characteristics of the process of aerosol formation of anthracene compositions

\begin{tabular}{|c|c|c|c|c|c|}
\hline $\begin{array}{c}\text { Number of } \\
\text { composition }\end{array}$ & Component & $\begin{array}{l}\text { Content, } \\
\text { wt.\% }\end{array}$ & $\begin{array}{l}\text { Duration of combustion } \\
\text { initiation, } s\end{array}$ & $\begin{array}{c}\text { Duration of intensive } \\
\text { smoke emission, } s\end{array}$ & $\begin{array}{l}\text { Combustion uniformity and } \\
\text { density of the aerosol cloud }\end{array}$ \\
\hline \multirow[b]{2}{*}{1} & $\mathrm{KClO}_{3}$ & 52.00 & \multirow{2}{*}{5} & \multirow{2}{*}{45} & \multirow{2}{*}{$\begin{array}{l}\text { Flashes while burning the } \\
\text { mixture. Dense smoke cloud }\end{array}$} \\
\hline & $\mathrm{C}_{14} \mathrm{H}_{10}$ & 48.00 & & & \\
\hline \multirow{2}{*}{2} & $\mathrm{KClO}_{3}$ & 53.00 & \multirow{2}{*}{5} & \multirow{2}{*}{45} & \multirow{2}{*}{$\begin{array}{l}\text { Flashes while burning the } \\
\text { mixture. Dense smoke cloud }\end{array}$} \\
\hline & $\mathrm{C}_{14} \mathrm{H}_{10}$ & 47.00 & & & \\
\hline \multirow{3}{*}{3} & $\mathrm{KClO}_{3}$ & 53.00 & \multirow{3}{*}{7} & \multirow{3}{*}{48} & \multirow{3}{*}{$\begin{array}{l}\text { Ripple during combustion } \\
\text { mixture. No dense smoke clou }\end{array}$} \\
\hline & $\mathrm{C}_{14} \mathrm{H}_{10}$ & 46.95 & & & \\
\hline & $\mathrm{MgCO}_{3}$ & 0.05 & & & \\
\hline \multirow{3}{*}{4} & $\mathrm{KClO}_{3}$ & 53.00 & \multirow{3}{*}{6} & \multirow{3}{*}{40} & \multirow{3}{*}{$\begin{array}{l}\text { Ripple during combustion } \\
\text { mixture. No dense smoke clou }\end{array}$} \\
\hline & $\mathrm{C}_{14} \mathrm{H}_{10}$ & 46.90 & & & \\
\hline & $\mathrm{MgCO}_{3}$ & 0.10 & & & \\
\hline \multirow{3}{*}{5} & $\mathrm{KClO}_{3}$ & 53.00 & \multirow{3}{*}{5} & \multirow{3}{*}{42} & \multirow{3}{*}{$\begin{array}{l}\text { Ripple during combustion } \\
\text { mixture. No dense smoke clou }\end{array}$} \\
\hline & $\mathrm{C}_{14} \mathrm{H}_{10}$ & 46.80 & & & \\
\hline & $\mathrm{MgCO}_{3}$ & 0.20 & & & \\
\hline \multirow{3}{*}{6} & $\mathrm{KClO}_{3}$ & 53.00 & \multirow{3}{*}{12} & \multirow{3}{*}{42} & \multirow{3}{*}{$\begin{array}{l}\text { Reducing the height of the } \\
\text { flames. Dense smoke cloud }\end{array}$} \\
\hline & $\mathrm{C}_{14} \mathrm{H}_{10}$ & 46.70 & & & \\
\hline & $\mathrm{MgCO}_{3}$ & 0.30 & & & \\
\hline \multirow{3}{*}{7} & $\mathrm{KClO}_{3}$ & 53.00 & \multirow{3}{*}{10} & \multirow{3}{*}{40} & \multirow{3}{*}{$\begin{array}{l}\text { Reducing the height of the } \\
\text { flames. Dense smoke cloud }\end{array}$} \\
\hline & $\mathrm{C}_{14} \mathrm{H}_{10}$ & 46.50 & & & \\
\hline & $\mathrm{MgCO}_{3}$ & 0.50 & & & \\
\hline \multirow{3}{*}{8} & $\mathrm{KClO}_{3}$ & 54.00 & \multirow{3}{*}{4} & & \\
\hline & $\mathrm{C}_{14} \mathrm{H}_{10}$ & 45.20 & & 35 & mixture No dense smoke clon \\
\hline & $\mathrm{MgCO}_{3}$ & 0.80 & & & \\
\hline & $\mathrm{KClO}_{3}$ & 54.00 & & & \\
\hline 9 & $\mathrm{C}_{14} \mathrm{H}_{10}$ & 45.00 & 3 & 42 & Rupple during combustion \\
\hline & $\mathrm{MgCO}_{3}$ & 1.00 & & & \\
\hline & $\mathrm{KClO}_{3}$ & 54.00 & & & Uniform combustion of the \\
\hline 10 & $\mathrm{C}_{14} \mathrm{H}_{10}$ & 44.90 & 5 & 45 & mixture and release of smoke. \\
\hline & $\mathrm{MgCO}_{3}$ & 1.10 & & & Dense smoke cloud \\
\hline & $\mathrm{KClO}_{3}$ & 54.00 & & & Uniform combustion of the \\
\hline 11 & $\mathrm{C}_{14} \mathrm{H}_{10}$ & 44.50 & 5 & 60 & mixture and release of smoke. \\
\hline & $\mathrm{MgCO}_{3}$ & 1.50 & & & Dense smoke cloud \\
\hline
\end{tabular}

in Table 1) yields uniform (without flares and ripples) burning of the mixture and the formation of a dense smoke cloud for $60 \mathrm{~s}$.

To ensure the required duration of initiation of the combustion process and the uniform generation of the aerosol, small amounts of thiourea (up to 1 wt.\%) can be added to the composition [5]. In the case of rapid heating to $180^{\circ} \mathrm{C}$, thiourea melts and decomposes gradually to form carcinogenic compounds. The effect of thiourea addition on the characteristics of the aerosol formation process is shown in Table 2.

It was found that the combustion of composition no. 1 (Table 2) was accompanied by the appearance of ripples and, accordingly, the irregularity of aerosol cloud generation. Therefore, the content of oxidant (potassium chlorate) in the compositions was increased from 53 to 55 wt.\% (compositions nos. 2, 3, 4, 5, and 6 in Table 2).

An increase in thiourea content from 0.2 to 1 wt.\% (with the same content of potassium chlorate in the compositions) caused a decrease in the duration of the combustion initiation from 5 to $3 \mathrm{~s}$ (i.e by 1.7 times) and the duration of intense smoke from 20 to $15 \mathrm{~s}$ (by 25\%). The uniformity of aerosol formation was ensured, and the combustion was accompanied by a sound effect.

Therefore, anthracene compositions containing a flame extinguisher (magnesium carbonate) and characterized by uniform combustion and prolonged generation of black aerosol are more suitable for camouflage of personnel and equipment in combat. Thiourea, being added to the anthracene-based compositions, increases their combustion rate, which 
Table 2

Effect of thiourea on the characteristics of the process of aerosol formation of anthracene compositions

\begin{tabular}{|c|c|c|c|c|c|}
\hline $\begin{array}{l}\text { Number of } \\
\text { composition } \\
\end{array}$ & Component & $\begin{array}{c}\text { Content, } \\
\text { wt. } \%\end{array}$ & $\begin{array}{c}\text { Duration of combustion } \\
\text { initiation, } \mathrm{s}\end{array}$ & $\begin{array}{c}\text { Duration of intensive } \\
\text { smoke emission, } \mathrm{s}\end{array}$ & Burn uniformity \\
\hline \multirow[t]{3}{*}{ 个 } & $\mathrm{KClO}_{3}$ & 53.0 & \multirow{3}{*}{5} & \multirow[t]{3}{*}{50} & \multirow{3}{*}{$\begin{array}{l}\text { Ripple during burning of the } \\
\text { composition }\end{array}$} \\
\hline & $\mathrm{C}_{14} \mathrm{H}_{10}$ & 46.5 & & & \\
\hline & $\left(\mathrm{NH}_{2}\right)_{2} \mathrm{CS}$ & 0.5 & & & \\
\hline \multirow{3}{*}{2} & $\mathrm{KClO}_{3}$ & 55.0 & \multirow{3}{*}{5} & \multirow{3}{*}{20} & \multirow{3}{*}{$\begin{array}{l}\text { Uniform rapid burning of the } \\
\text { composition }\end{array}$} \\
\hline & $\mathrm{C}_{14} \mathrm{H}_{10}$ & 44.8 & & & \\
\hline & $\left(\mathrm{NH}_{2}\right)_{2} \mathrm{CS}$ & 0.2 & & & \\
\hline \multirow{3}{*}{3} & $\mathrm{KClO}_{3}$ & 55.0 & \multirow{3}{*}{4} & \multirow{3}{*}{18} & \multirow{3}{*}{$\begin{array}{l}\text { Uniform rapid burning of the } \\
\text { composition }\end{array}$} \\
\hline & $\mathrm{C}_{14} \mathrm{H}_{10}$ & 44.7 & & & \\
\hline & $\left(\mathrm{NH}_{2}\right)_{2} \mathrm{CS}$ & 0.3 & & & \\
\hline \multirow{3}{*}{4} & $\mathrm{KClO}_{3}$ & 55.0 & \multirow{3}{*}{3} & \multirow{3}{*}{16} & \multirow{3}{*}{$\begin{array}{l}\text { Uniform rapid burning of the } \\
\text { composition }\end{array}$} \\
\hline & $\mathrm{C}_{14} \mathrm{H}_{10}$ & 44.5 & & & \\
\hline & $\left(\mathrm{NH}_{2}\right)_{2} \mathrm{CS}$ & 0.5 & & & \\
\hline \multirow{3}{*}{5} & $\mathrm{KClO}_{3}$ & 55.0 & \multirow{3}{*}{3} & \multirow{3}{*}{16} & \multirow{3}{*}{$\begin{array}{l}\text { Uniform rapid burning of the } \\
\text { composition }\end{array}$} \\
\hline & $\mathrm{C}_{14} \mathrm{H}_{10}$ & 44.4 & & & \\
\hline & $\left(\mathrm{NH}_{2}\right)_{2} \mathrm{CS}$ & 0.6 & & & \\
\hline \multirow{3}{*}{6} & $\mathrm{KClO}_{3}$ & 55.0 & \multirow{3}{*}{3} & \multirow{3}{*}{15} & \multirow{3}{*}{$\begin{array}{l}\text { Uniform rapid burning of the } \\
\text { composition }\end{array}$} \\
\hline & $\mathrm{C}_{14} \mathrm{H}_{10}$ & 44.0 & & & \\
\hline & $\left(\mathrm{NH}_{2}\right)_{2} \mathrm{CS}$ & 1.0 & & & \\
\hline
\end{tabular}

is accompanied by a characteristic sound effect and, accordingly, the duration of aerosol generation. Therefore, these compositions can be used during filming, in particular for the imaging of battle scenes.

\section{Conclusions}

It is found that the content of magnesium carbonate (a flame extinguisher) in the anthracene composition should be $1.5 \mathrm{wt} \% \%$ that provides combustion without flares and ripples and ensures a dense black smoke cloud for $60 \mathrm{~s}$.

The reduction in the duration of combustion initiation of the anthracene composition and the duration of intense smoke emission was stated when increasing the content of thiourea from 0.2 to $1.0 \mathrm{wt} . \%$. The addition of thiourea contributes to the uniformity of the combustion.

Anthracene-based compositions containing magnesium carbonate can be applied to generate black aerosols for the protection of personnel and equipment in combat. The compositions with thiourea can be used during filming.

\section{Acknowledgments}

The work was performed within the scope of the contract No. 0603 «Development of compositions for aerosol generation with specified electron-optical characteristics and means with flame retardant properties» (2019). The authors are grateful for the financial support from the SPPP Sparring-West Center staff.

\section{REFERENCES}

1. Melnikov V.E. Sovremennaya pirotekhnika. - M.: Tipografiya Nauka, 2014. - 480 p.

2. Chepil I.N., Radchenko I.A., Pisarev S.A. Maskiruyushchiye svoistva aerozolnykh zaves // Systemy Obrobky Informatsii. - 2002. - No. 2(18). - P.209-211.

3. Ayerozoli - dispersnye sistemy / Chekman I.S., Syrovaya A.O., Andreyeva S.V., Makarov V.A. - Kharkiv: Tsyfrova Drukarnia, 2013. - $100 \mathrm{p}$.

4. Patent 2541025 RU. Pirotekhnicheskiy sostav chernogo dyma / Reznikov M.S., Mingazov A.Sh., Sidorov A.I., Ginzburg V.L., Lutsenko M.V., Lokshin O.V. (Russian Federation). - No. 2160132564; Publ. 10.02.2015. - 4 p.

5. Shidlovskiy A.A. Osnovy pirotekhniki. - M.: Mashinostroyeniye, 1973. - $320 \mathrm{p}$.

6. Veytser Yu.I., Luchinskiy G.P. Maskiruyushchiye dymy. - M.-L.: GNTIKhL, 1947. - 202 p.

7. Utemov S.V. Metodika obosnovaniya trebovaniy $\mathrm{k}$ prostranstvennym kharakteristikam lokalnogo ayerozolnogo obrazovaniya dlya preryvaniya videniya tseli operatorom // Vestnik Voronezhskogo gosudarstvennogo tekhnicheskogo universiteta. 2011. - Vol.7. - No. 3. - P.29-32.

8. Platov G.A. Pirotekhnik. Iskusstvo izgotovleniya feyerverkov. - M.: Izdatelstvo Knizhkin Dom, Izdatelstvo Eksmo, 2005. $-320 \mathrm{p}$.

9. Patent $2350590 R U$, MPK C06D 3/00 (2006.01), C06B 29/02 (2006.01). Pirotekhnicheskiy dymoobrazuyushchiy sostav / Emelyanov V.N., Vagonov S.N., Varenykh N.M., Zakharova Z.A. 
(Russian Federation). - No. 140803/02; Claim. 07.11.2007; Publ. 27.03.2009, bull. - No. 9. -5 p.

10. Patent 2528851 RU, MPK C06D 3/00 (2006.01). Pirotekhnicheskiy sostav chernogo dyma / Reznikov M.S., Sidorov A.I., Lutsenko M.V., Lokshin O.V., Mingazov A.Sh., Ginzburg V.L., Gureeva E.V. (Russian Federation). - No. 129106/05; Claim. 27.06.2013; Publ. 20.09.2014, bull. No. 26. - 6 p.

11. Chuvurin A.V. Zanimatelnaya pirotekhnika: opasnoye znakomstvo: V 2 ch. - Ch. 1. - Kharkov: Osnova, 2003. -360 p.

12. Chuvurin A.V. Zanimatelnaya pirotekhnika: feyerverk svoimi rukami: V 2 ch. - Ch. 2. - Kharkov: Osnova, 2003. - 364 p.

Received 23.09.2019

\section{ЕНЕРГОКОНДЕНСОВАНІ КОМПОЗИЦІЇ ДЛЯ ГЕНЕРУВАННЯ АЕРОЗОЛЬНИХ ЗАВІС ЧОРНОГО КОЛЬОРУ}

\section{3.О. Знак, Ю.В. Сухацький, А.Б. Гелеш, Р.В. Мних}

У роботі наведено результати досліджень впливу додатків різної хімічної природи та функційного призначення (магній карбонату, тіосечовини) на процеси генерування аерозолів чорного кольору, зокрема рівномірність горіння композицій, тривалість інтенсивного димовиділення і щільність аерозольної завіси. Встановлено, що додавання магній карбонату (погашувача полум'я) до складу антраценової композиції в кількості, що перевищуе 0,2 мас.\%, істотно збільшуе тривалість ініціювання процесу горіння (у 2-2,4 рази) і сприяє зменшенню висоти полум'я та частоти спалахів. При цьому тривалість інтенсивного димовиділення зменшується на 6,7-11,1\%, а загальна середня тривалість процесу аерозолеутворення (тривалість ініціювання горіння +тривалість інтенсивного димовиділення) залишається незмінною і становить приблизно $50 \mathrm{c}$. 3'ясовано, що збільшення вмісту магній карбонату в композиції понад 0,5 мас.\% суттево ускладнює ї̈ загоряння, а тому для досягнення необхідного температурного режиму горіння необхідно збільшувати вміст окисника (калій хлорату) у композиціі. Виявлено, що збільшення вмісту магній карбонату в антраценових композиціях від 0,8 до 1,5 мас.\% (за одночасного зменшення вмісту антрацену) зумовлює збільшення загальної тривалості аерозолеутворення в 1,7 рази (від 39 до 65 c) та забезпечує дотримання вимог щодо його основних характеристик (рівномірності горіння композицій, тривалості інтенсивного димовиділення та щільності аерозольної завіси). Встановлено зменшення тривалості ініціювання горіння антраценової композиції (в 1,7 рази) і тривалості інтенсивного димовиділення (на 25\%) за збільшення вмісту тіосечовини в композиції від 0,2 до 1,0 мас.\%. Можливими сферами використання антраценових композицій з додатками магній карбонату є військова сфера (для генерування аерозольних завіс чорного кольору із маскувальними властивостями для захисту особового складу $i$ техніки), а з додатками тіосечовини - кінозйомки (імітація батальних сцен).

Ключові слова: енергоконденсована композиція, антрацен, аерозоль, чорний дим, маскувальна здатність, магній карбонат, тіосечовина.

\section{ENERGY-CONDENSED COMPOSITIONS FOR GENERATION OF BLACK AEROSOL CLOUDS}

\section{Z.O. Znak *, Yu.V. Sukhatskiy, A.B. Helesh, R.V. Mnykh}

Lviv Polytechnic National University, Lviv, Ukraine

*e-mail: znak_zo@ukr.net

The paper reports the influence of additives with different chemical nature and functional purpose (magnesium carbonate and thiourea) on the processes of generating black aerosols, in particular, the uniformity of the combustion of compositions, the duration of intense smoke and the density of the aerosol cloud. It is established that the addition of magnesium carbonate (flame extinguisher) to the anthracene composition in the amount exceeding $0.2 \mathrm{wt} . \%$ increases the duration of combustion initiation (by 2-2.4 times) and decreases the flame height and flash frequency. In this case, the duration of intense smoke decreases by $6.7-11.1 \%$, and the total average duration of the aerosolization process (i.e. the duration of combustion initiation together with the duration of intense smoke) remains unchanged and is about $50 \mathrm{~s}$. It is found that an increase in magnesium carbonate content in the composition of more than $0.5 \mathrm{wt} . \%$ significantly complicates ignition. Therefore, it is necessary to increase the content of oxidant (potassium chlorate) in the composition to achieve the required combustion temperature. An increase in magnesium carbonate content in anthracene compositions from 0.8 to $1.5 \mathrm{wt} . \%$ (while reducing anthracene content) causes an increase in the total duration of aerosol formation by 1.7 times (from 39 to $65 \mathrm{~s}$ ) and ensures compliance with its basic characteristics (the uniformity of combustion of compositions, the duration of intense smoke and the density of the aerosol cloud). The reduction of the duration of combustion initiation of the anthracene composition (by 1.7 times) and the duration of intense smoke emission (by 25\%) was observed when increasing the thiourea content in the composition from 0.2 to $1.0 \mathrm{wt} . \%$. The possible areas of the use of anthracene compositions with the additives of magnesium carbonate and thiourea are military sphere (to generate aerosol clouds of black color with masking properties for the protection of personnel and equipment) and filming (to imitate the battle scenes), respectively.

Keywords: energy-condensed composition; anthracene; aerosol; black smoke; camouflage ability; magnesium carbonate; thiourea.

\section{REFERENCES}

1. Melnikov V.E., Sovremennaya pirotekhnika [Modern pyrotechnics]. Tipografiya Nauka Publishers, Moscow, 2014. 480 p. (in Russian).

2. Chepil I.N., Radchenko I.A., Pisarev S.A. Maskiruyushchiye svoistva aerozolnykh zaves [Masking properties of aerosol curtains]. Systemy Obrobky Informatsii, 2002, no. 2 (18), pp. 209-211. (in Russian).

3. Chekman I.S., Syrovaya A.O., Andreyeva S.V., Makarov V.A., Ayerozoli - dispersnye sistemy [Aerosols as dispersed systems]. Tsyfrova Drukarnia Publishers, Kharkiv, 2013. 100 p. (in Russian).

4. Reznikov M.S., Mingazov A.Sh., Sidorov A.I., Ginzburg V.L., Lutsenko M.V., Lokshin O.V., Pirotekhnicheskii sostav chernogo dyma [Pyrotechnic composition of black smoke]. Patent RU, no. 2160132564, 2015. (in Russian).

5. Shidlovskiy A.A., Osnovy pirotekhniki [Fundamentals of pyrotechnics]. Mashinostroyeniye Publishers, Moscow, 1973. 320 p. (in Russian). 
6. Veytser Yu.I., Luchinskiy G.P., Maskiruyushchiye dymy [Masking smokes]. GNTIKhL Publishers, Moscow-Leningrad, 1947. 202 p. (in Russian).

7. Utemov S.V. Metodika obosnovaniya trebovanii k prostranstvennym kharakteristikam lokal'nogo aerozolnogo obrazovaniya dl'ya preryvaniya videniya tseli operatorom [Methodology for substantiating the requirements for the spatial characteristics of a local aerosol formation to interrupt the operator's vision of the target]. Vestnik Voronezhskogo Gosudarstvennogo Tekhnicheskogo Universiteta, 2011, vol. 7, no. 3, pp. 29-32. (in Russian).

8. Platov G.A., Pirotekhnik. Iskusstvo izgotovleniya feyerverkov [Pyrotechnician: the art of making fireworks]. Knizhkin Dom Eksmo Publishers, Moscow, 2005. 320 p. (in Russian).

9. Emelyanov V.N., Vagonov S.N., Varenykh N.M., Zakharova Z.A., Pirotekhnicheskii dymoobrazuyushchii sostav [Pyrotechnic smoke-forming composition]. Patent RU, no. 140803/02, 2009. (in Russian).

10. Reznikov M.S., Sidorov A.I., Lutsenko M.V., Lokshin O.V., Mingazov A.Sh., Ginzburg V.L., Gureeva E.V., Pirotekhnicheskii sostav chernogo dyma [Pyrotechnic composition of black smoke]. Patent RU, no. 129106/05, 2014. (in Russian).

11. Chuvurin A.V., Zanimatelnaya pirotekhnika: Opasnoye znakomstvo [Entertaining pyrotechnics: dangerous acquaintance]. Osnova Publishers, Kharkiv, 2003. 360 p. (in Russian).

12. Chuvurin A.V., Zanimatelnaya pirotekhnika: Feyerverk svoimi rukami [Entertaining pyrotechnics: do-it-yourself fireworks]. Osnova Publishers, Kharkiv, 2003. 364 p. (in Russian). 